\title{
Teacher Education, Teacher Preparation and Professional Development of Secondary Schoolteachers in Light of Recent Global Trends
}

\author{
Bannaga Taha El-Zubair ${ }^{1}$, El-Rusheed Habob Mohammed ${ }^{1}$, Huda Salem Alkubaisi ${ }^{2}$ \\ ${ }^{1}$ Department of Foundations and Administration of Education, Faculty of Education, University of Khartoum \\ ${ }^{2}$ Department of Educational Sciences, College of Education, Qatar University, Qatar \\ Correspondence: Bannaga Taha El-Zubair, Department of Foundations and Administration of Education, Faculty of \\ Education, University of Khartoum.
}

Received: August 7, 2019

doi:10.11114/jets.v7i11.4434
Accepted: September 8, 2019 Online Published: September 16, 2019

URL: https://doi.org/10.11114/jets.v7i11.4434

\begin{abstract}
The purpose of this study is to present a brief overview of the nature of teacher education and preparation programs, and the professional development of secondary schoolteachers in the Arab world, and to offer insights into recent global trends in the matter.

By examining some of the relevant literature and scholarly work, this study's main objective is to provide a comprehensive picture of the teacher-program-related policies offered by education colleges/institutions in the region in the light of global trends. To achieve this, the researchers surveyed most of the existing related studies conducted in the region. This was pursued through analysis of evidence, methodologies, underlying ideologies, and indicators of examined literature. Similarly, an analysis of publications relating to recent global trends was undertaken.

Results suggest that a comprehensive "five-year" teacher programs is ideal to be integrated into higher education in the Arab world due to its feasibility, affordability as well as lower financial costs. It was found that that the components of existing teacher programs must be subject to evaluation and review for further development. However, the results indicate not only that the strategy of candidate admission and enrollment in colleges are not based on appropriate criteria, but also that a clear policy for teaching licensure is ignored.

The study emphasizes the need to establish fully equipped teacher training centers. To attain this, we strongly suggest selecting or creating well-equipped and administratively affiliated schools to the colleges to provide an experimental environment for candidates to practice what they have learned. Achieving a balance between different course packages should be considered.
\end{abstract}

Keywords: teacher education programs, teacher preparation programs, secondary schooling, global trends

\section{Introduction}

Educational systems around the world are always concerned with the teaching profession, particularly in terms of the process of teacher education and preparation, professional development and training to improve performance and teaching efficiency on the one hand, and enhancing pay, social status and other necessary resources of teachers on the other hand. In the United States (US), for instance, competent and well-qualified teachers are recognized as a key source for leadership across the world. As such, responding to the noticeable increase in population, pre-education committees used to constantly call for the selection and preparation of a sufficient number of qualified and capable teachers in order to cope with the expansion of varied levels and sectors in the educational system. This aligns with the concurrent demands for paying special attention to the programs of teacher selection and preparation, and part of that is teacher training and continuous professional development curriculum and pedagogy so as to meet the demands of the job market. Preparing in colleges and then graduating teachers is not enough and would not be effective unless they have required pedagogical knowledge and professional skills to teach appropriately. Adequate professional development for teachers could boost their performance. Therefore, it is entirely acceptable that the necessary skills should be developed for teachers, especially in high-demand fields such as mathematics, science and technology.

\section{Problem and Significance of the Study}

Teachers are a key element in educational systems. They are not only seen as effective instruments for education 
improvement, but as leaders who can influence students' development and schooling. It is argued that the greatest, distinguished and creative thinkers and scientists reached what they attained only because they had been taught and concerned by competent and good teachers in their early lives. In other words, a teacher is a crucial element in the educational process as he/she always plans, creates student`s learning experiences and activities, and actively involves them in these activities.

In a speedily changing world that has obliged education authorities to scrutinize how their educational colleges/institutes prepare future teachers to capably join the market, to effectively involve students in teaching and learning, and to smoothly respond to globalization. Thus, teacher education and teacher preparation are a milestone issue for education systems. Professionally prepared teachers are better committed to and aware of students' varied needs and abilities, and can deal with them effectively. Professional development programs hugely contribute to how teachers demonstrate such behavior in their classrooms. Research has found a positive impact for teacher education, preparation and certificates on student outcomes (Darling-Hammond, 2000; Goe, 2002; Wenglinsky, 2000). Moreover, teachers' effectiveness is seen to be significantly correlated to teacher preparation and teacher education in institutes (Darling-Hammond, Holtzman, Gatlin and Heilig, 2000). Moreover, educational institutes "are in the knowledge business [...], they disseminate or retail knowledge through their teaching function" (Hunt, 1992, as cited in Madhavaram \& Laverie, 2010, p. 197). This necessitates that all teachers and their institutes/colleges be constantly aware of their roles and functions in the light of recent global trends. For Bray (2005, p. 44), "[m]odern education systems are still organized locally and nationally, and are still subject to national regulation". Especially, those teachers, as educators, are required to be eager and to explicitly benefit from each single opportunity provided (Madhavaram \& Laverie, 2010).

\section{Objectives and Questions of the Study}

This study examines the teacher education and preparation programs in education colleges and in-service on-going professional development for teachers in the Arab world. By exploring the actual situation and challenges, more insights will be added to the topic so as to better understand it. In this way, the countries in the region would benefit from the contemporary global trends in teacher education and preparation programs and candidate admission and enrolment different policies in colleges of education.

The study aims to understand the way in which teacher education and preparation programs at education colleges in the Arab world function in view of recent global trends in relation to selection, admission and enrolment policies, and in-service on-going professional development. It also seeks to explore and highlight the experiences and main aspects of teacher education in some of the developed countries from which lessons can be learned. This fits with clear evidence that the provision of teacher professional development must be addressed and designed aligning to recent global trends (Al-Mustafa, 2010).

From the above discussion, the problem of the study may be reflected in the form of the following research question: how can secondary schoolteachers in the Arab World be professionally developed in the light of recent global trends?

To answer this main question, three sub-questions were considered, which are as follows:

1) What are the recent global trends in students` admission and enrollment policies in colleges of education?

2) What are the recent global trends regarding student-teacher (candidate) education and preparation programs in colleges of education?

3) What are the most recent global trends relating to teachers' professional development?

\section{Limitations of the Study}

This study is limited to identifying issues relating to education and preparation programs at education colleges in Arab World function in view of recent global trends of teacher education and preparation programs in colleges: selection, admission and enrolment policies, and in-service on-going professional development. Previously, it was limited to: (1) teacher education and teacher education and preparation programs and professional development of secondary schools; and (2) student-teacher candidate admission and enrollment policies in education colleges/institutions in the Arab world. Additionally, the study was based on the literature review, in particular, in Arabic language scholarly work during the academic year from September 2017 to June 2018.

\section{Term and Definition}

In this paper, following Gibrael (1983), we define teacher education and preparation as, the preliminary process of making student-teacher (candidate) as a professional in teaching in the educational institutions, such as educational centers, college of education (or teacher college as it is referred to in some developed countries) and affiliations, in 
which in pedagogical knowledge, specialized taught courses and practices are provided according to each educational levels. By this, each candidate will be culturally, academically and educationally prepared as pre-service before joining the market.

In this paper, we conceptualize professional development as an organized and pre-planned process for the addition of new educational, administrative and teachers pedagogical knowledge and professional and personal skills building to build their capacity as professionals, oriented towards increasing teacher`s achievement qualitatively and quantitatively (Abdalsalam, 2006).

Recent global trends: we also describe the term "recent global trends" in reference to any new developments, innovations and globally existing knowledge in relation to the discussed topic i.e. student-teacher (candidate) admission and enrollment policies, teacher education and preparation programs in educational institutes and colleges, and teacher in-service on-going professional development and training.

\section{Methodology}

This study has relied on rigorous descriptive methods through documentary analysis that were carefully followed. Special efforts have been exerted to examine and highlight the most recent and recent global trends in the field. To achieve this, a descriptive analytic method was utilized in order to examine some existing relevant literature on the topic, which was systemically analyzed using an inductive process.

The researchers believe in the significance of contemporary programs of teacher education and professional development. This is undoubtedly a desirable aim for any education system as it is unacceptable to have teachers who will be limited in scopes of knowledge and skills throughout their professional lives, bearing in mind the rapid change taking place globally in different fields. Needless to mention the concurrent groundbreaking improvements in communications and technology, which have led to a remarkable pace and extraordinary engagement in the generation and use of technical and scientific knowledge. Within this revolution of education, the required potential teachers for many nations are those who can continuously and professionally develop themselves and utilize knowledge and multiple skills pertaining to teaching and learning that they have gained academically. Therefore, selecting potential candidates to pursue teacher programs is essential.

It is perceived that teacher education and preparation is not a relaxed process. Consequently, the development of appropriate educational planning that seeks to provide prospective teachers with the necessary educational services during preparation - to give them awareness of and commitment to global developments and endeavors in education, science and technology - is a demand for nation-states. Especially since the implications of the global experiences in the field to improve and develop practices for teacher preparations and trainings at the college level are not specific to colleges of education in the Arab world. Moreover, it might be helpful to develop a framework for measurable competencies and skills as well as good practices for teachers. Linking this framework to professional standards may also profoundly improve teacher's performance. For example, when a teacher performs certain practices that meet a particular level of standards, he/she would be qualified to attain a professional license for teachers. However, a licensure process "may professionalize teacher practices but may not solve the under-preparedness of teachers" (Ellili-Cherif, Romanowski \& Nasser, 2011, p. 474). It should also be noted that local standards (in any Arab country) must be driven by international curriculum standards and benchmarks. Ferguson (1991) has found that teachers' performance as tested by licensing procedures positively heeds progress in student achievement. To do this successfully, Ahmed (2007) emphasizes that well-trained and qualified educational supervisors/leaders, who can change and improve teachers' classroom behavior, are essential because this helps teachers to manage all possible situations.

\section{Features of Pre-Service Teacher Education and Teacher Preparation}

The importance of the role of the teacher increases day after day. Teacher role involves several levels, actions and responsibilities from engagement to commitment both inside and outside of the classroom. He/she involves, supports and is directed towards the external community and environment in which a teacher exists. In addition to other factors, cultural levels and the development of a teacher must be taken into account. Recognizing the instability of these factors, teacher education and preparation must take various forms and shapes if it is to comply with each stage of change (Abdalsalam, 2006).

Equally important, teacher preparation should be considered within a future prospective, which largely necessitates personal preparation and the willingness of potential teachers themselves to explore the impact of the global context on their professional development in order to efficiently perform their roles as teachers. From our point of view, this is due to the fact that a teacher is supposed to have unique and typical characteristics which transpire from a unique normal personality, behaviors, attitudes, interests and values. Therefore, the teacher for us is a model. In other words, his/her character reflects on his/her students' behaviors, and directly or indirectly on the students' personalities. However, in 
relation to achieving the aim of the study, some teachable aspects of teacher education and preparation programs are outlined below. They reflect in particular the academic, professional and cultural components of any potential, rigorous and well-organized program, rather than focusing on the political, social and comical components.

Overall, teacher education and preparation require that all candidates must complete particular program courses, which embodies the following teachable aspects of content:

I. Academic aspects: aiming to provide the most relevant academic and pedagogical knowledge, professional training and fieldwork in core (compulsory) and optional courses/subjects to prepare teachers academically and enrich their backgrounds to understand the field and realize new pedagogical and scientific concepts and facts, which is presumed to allow them the opportunity to first-handily share and adopt new knowledge and practices. In addition, this feature supports the development of candidates' ability to think scientifically and academically, and provide them with the pedagogical content knowledge related to their teaching specific subject matter knowledge. Specifically, today's scientific concepts and facts revolutionary increase and rapidly change (Wajeeh \& Michael, 2006).

II. Cultural aspects: seeking to offer candidates with understanding and awareness of human culture as a whole, as well as the social norms, cultural values and heritage of the context in which they live in and in which they are asked to teach. It is assumed that if the teacher possesses a satisfactory and sufficient awareness of general knowledge and other subject contents rather than only one's subject area, then the level of students' confidence and respect is likely to be high. Moreover, this will largely shape a teacher's personality and considerably widen one's horizon and thinking in order to perform his/her anticipated social role and to better appreciate the needs of his or her external community.

III. Educational aspects: the process of preparing the candidate academically, educationally and professionally during their study in colleges and institutions heavily focuses on empowering the candidate in terms of acquisition of positive values and attitudes toward the profession e.g. determination, communication, respect, trust, patience and reliability. Therefore, educational and psychological preparation is central to the life of a student-teacher along with other relevant concepts, theories, ideas and recent trends in the field of education, science of teaching, and particularly in the mastery of specific subject area knowledge (Wajeeh \& Michael, 2006).

IV. Scientific aspects: these represent the most important and active component of teacher education and preparation academic programs. This implies giving more care and attention to implementation of various techniques and approaches that can enable the transformation of the student-teacher in colleges to a skilled professional teacher who is capable of teaching, practicing teaching in classroom effectively and successfully, and adapting their academic program accordingly. Within this feature, practices like educational, technology, microteaching, teaching and learning are heavily used and depended on (Al-Beelawi, 2004).

\section{Recent Global Trends in Teacher Professional Development}

\section{1) Recent Global Trends in Student's Admission and Enrollment Policy in Colleges of Education}

In this section, the distinctive features of admission and enrollment policy in educational institutions in some developed countries are highlighted.

\section{In Finland}

Evagorou, Dillon, Viiri and Albe (2015) indicate that the first-ever teacher training college in Finland was established in 1873 for elementary schooling education. The authors, in highlighting teacher education and preparation in the country, assert that teachers' qualification requirements, degrees and work in schools are regulated by the national board of education and described in the framework of the universities that offer teacher education programs. They further illustrate that these programs are based on a research-orientated teacher who is open to systemically adopting and developing teaching methods, skills and approaches upon one's analysis and observation in classroom. Therefore, learning and conducting research at university level is an important element in the program in Finland.

Evagorou, Dillon, Viiri and Albe (2015) also outline the following features of the Finnish teacher education program:

- A five-year dual-track compulsory schooling program is provided to prepare Finnish teachers that end with a Master's in Education or a particular subject (e.g. physics) degree and most of whom are recruited in schools.

- There are two academic teacher education programs in the Finnish schooling system. One is the preparation program for 'primary level class-teacher' for which candidates' are selected in two stages: (1) upper secondary school graduates nominated after succeeding in university-based standardized paper-and-pencil tests, and (2) examining the nominees through interviews and personality surveys in each university, which is the main 
selection criterion. It should be noted that little guidance is provided for this group of teachers in the way of teaching specific course/subjects e.g. science. Another preparation program is 'secondary level subject-based teacher', while the selection process relates to distributing students to their main subject track. Educational and subjects colleges are jointly responsible for training this group of teachers. However, while the program structure is similar in all colleges, they differ in curriculum contents and the nature of courses. Furthermore, the school curriculum is developed according to the national curriculum framework.

- Students become qualified and licensed teachers and offering an open market after graduation. Job offers are available online, newspapers and teacher union publications.

In the US

Al-Deeb (1992) describes how students join and are admitted into education colleges in US system. He indicates the following criteria as compulsory for enrolling a candidate student:

- The completion of two years at college.

- Being passionate and interested in joining teaching academic programs and thereafter teaching profession as a schoolteacher.

- The application for enrollment in the academic programs in colleges should be made four weeks before actual study begins.

- A 'free of infective and psychotic diseases' medical certificate which must be provided and attached to the application.

- A contract between the candidate and the Dean of the college which must be drawn and signed by both. This shows a candidate's confirmation and willingness to abide by the regulations and, more importantly, to complete the prescribed offered courses in the specific program.

- Passing exams on all professional and educational courses outlined in the program plan.

- Attaining a grade that is no less than 2.5 (out of 4) in each specialized and secondary course/subject shown in the prescription of the program and its credit hours.

- Achieving an average grade or more in the core courses/subjects of study program e.g. teaching methods, special education and microteaching.

\section{In France}

Ghunaima (1996) outlines the policy of admission and enrollment in French education colleges/institutions as follows:

$\square$ Selection of the most proficient candidates before the final approval of enrollment in education and preparation programs.

$\square \quad$ Passing exams on school competence tests.

$\square$ Passing personality tests, which aim to determine the degree of the willingness of the candidate to join the teaching profession, and to ensure his or her interest in dealing with students of different ages, backgrounds, developmental levels, motivations and prior knowledge.

$\square \quad$ Mastery of relevant skills that potential teachers demonstrate before the candidate finally admitted in the program.

$\square$ Candidates that graduated with a Diploma or equivalent as schoolteachers of primary schools are subject to additional testing.

Candidates applying for admission for secondary schoolteacher programs should complete a three-year university program that ends with the award of a Bachelor's degree, or four-year program that ends by obtaining either 'The certificate of competence in teaching at secondary schools' or 'The certificate of competence in teaching in technical institutes'.

\section{In $U K$}

According to Ketsh (2001), for the candidate to be admitted to a UK-based educational institution, the following criteria should be met by the candidate in question:

Graduating with a university first-class degree in Education e.g. Bachelor of Education (B.Ed.)

$\square$ Passing two course/subjects of the "Post Graduate Certificate Education (PGCE) (Advanced level) and three subjects in GCSE Examination with the score of (good) or more, or its equivalent. 
$\square \quad$ English Language and Mathematics are part of the selected courses/subjects that the candidate examined in General Certificate Secondary Education (GCSE).

Relevantly, the policy of enrollment in teacher education and preparation program PGSE demands that the candidate must fulfill the following criteria:

1. Awarding of a university first-class degree or its equivalent.

2. Passing written, oral and health tests to ensure his or her eligibility for the teaching profession.

3. Testis and diagnostic assessments conducted under the supervision of experienced teachers. In Japan

Ketch (2001) indicates that the process of selection, admission and enrollment of candidates for joining Japan's educational institutions is restrictive and subject to the Education Council's regulations that is strictly implemented and followed. For example, the (student-teacher) candidate must have been awarded a university first degree, passed the eligibility test, and spent an additional academic year to study after completion the program or obtained a Master's degree. It should noted that this regulatory framework relates to candidates intending to teach in high or secondary schooling only.

\section{2) Global Trends Regarding Academic Programs in Educational Institutions/Colleges}

Teacher education and preparation academic programs in any country affect the quality of education in that country, as the competence of teachers depends largely on the prescribed academic programs designed for them before joining teaching as a profession. The more well-designed academic programs lead to more effective academic and educational preparation and, as a result, a more flourishing profession. Therefore, we as researchers join our voices alongside other scholars calling for special attention and care to be given to the programs for teaching and improvement, which reflects on the quality of education as a whole.

\section{3) Global Trend of Skill-Based Teacher Professional Development}

Teacher education and preparation programs in colleges may take many a form of skills-based professional development. This trend has eventually become highly attractive to such programs due to various limitations of teaching practices, and concerns and challenges sparked as a result of the global rapid changes, which have influenced the philosophy of teacher education and preparation programs. For example, when the teacher education and preparation philosophy is more concerned about developments of cognitive dimensions of the teacher, the academic programs are more able to improve teaching practices inside the classroom. This trend dates back to the 1970s, and is assumed that teacher's competences, performance, and pre- and post-service trainings are the key sources of good teaching, as well as teaching process which will be effectively analyzed according to a set of essential teaching skills. Thus, if the candidate or student-teacher manages to succeed in one's college, he/she is more likely to be a good teacher (Humood, 2003).

\section{4) Global Trend Regarding Applying Total Quality Standards in Colleges of Education}

There is agreement among researchers that universities should adopt and raise professional standards for teachers and principals as a requisite. Standards are vital educational concepts that have often been defined in a variety of ways. For example, Down (2012, p. 66) defines them as "a mechanism of ideological control." Other researchers refer to them as a capability of governing bodies to "clearly define what should be taught and learned, and able to monitor the progress of schools, principals, teachers, and students through various monitoring and assessment systems" (Zavadsky, 2009, p. 282). On other hands, Alawana (2004) refers to total quality as a comprehensive system can be applied at all education levels to satisfy students and others who may benefit from learning and instruction. He has further added that total quality management not only relates to sets of standards, procedures, specifications and characteristics expected to appear in the educational final product, as well as related activities, but also to a process of continuous improvement of an educational product.

According to Madani (2002), total quality is an appropriate framework to coordinate developing efforts for the following advantages:

$\square \quad$ It includes all features of academic and administrative practices at the university level as a whole, and therefore influences sorts of comprehensive change that can help in raising standards and competencies.

$\square \quad$ It possesses the capacity that builds a comprehensive and coordinated context that can bring all efforts together to achieve a common goal.

$\square \quad$ Calling for continuous teacher's improvement, development and practices. This undoubtedly is the integral role played by education and teacher colleges or any institution/center concerned with teacher education and preparation. 
Measurement, assessment and evaluation are likely the main procedures for development adopted in different ways for the purpose of inclusive teacher education and preparation. Some of these ways are academic programs, curriculum, recruitment, environment, school administration and management, student welfare, assessment and evaluation, and feedback.

\section{5) Global Trend Related to Academic Accreditation of Colleges of Education}

Globally, accreditation is an academic approach that is increasingly acknowledged as the right method for improving and developing the quality of university education. Practically, education colleges/institutions in universities are now more concerned about their programs being nationally accredited. In this sense, they use accreditation attempting to restructure and properly design their academic programs in order to have the ability to produce good teachers who can safely and confidently join teaching profession at all school levels (Al-Utaibi \& Ghalib, 1996) aligning with the neoliberalism trends. Moreover, academic accreditation may likely attain administrative and academic efficiency of the program and college if properly implemented and taken seriously. In turn, more reflection might be echoed on the production of high-quality graduates. Ahmad (2007) emphasizes that this would be an excellence indicator for both colleges and universities.

In this sense, we call for Arab countries to learn by looking at other developed countries' experiences in this area - i.e. accreditation - for the benefit of improving teacher professional development. This would be helpful to exchange and share ideas, practices and concerns. Adopting a global focus undoubtedly eases the roles and functions of the educational academic programs (Al-Badani \& Lulua, 2005).

Aligned to this, teacher education and preparation programs are implemented differently in different educational systems in developed countries. They are likely classified according to their major components in two main systems:

\section{Systems followed in programs of teacher education and preparation}

Many developed countries implement teacher preparation programs though one of two separate systems: complementary and consecutive teaching. Yahia (2003) illustrates these systems as follows:

a) Complementary component: this requires the candidate to study scientific, cultural and educational academic course/subjects jointly at the college level for four years ending with a Bachelor degree (B.Ed.).

b) Consecutive component: this obliges the candidate to study his/her scientific subject area in the mother college/institution that absolutely teaches that subject area - e.g. College of Arts or College of Science - and obtain a Bachelor's degree in that specific area i.e. BA or BSc. Then, graduates interested in teaching would be able to join one- or two-year program to continue their studies in teacher education and obtain a Diploma in Education.

It is important to note that both systems have their advantages and disadvantages. However, the complementary system is widely adopted particularly in Arab countries (Ahmed, 2007).

\section{Duration of Study}

Duration of study varies from one context to another, one country to another and one level of study to another. For example, in a "Pre-school teacher preparation programs" either as a first or second level, the duration is 4 years ending with a Bachelor's degree in that area in each of these levels. However, with regard to the duration of secondary school programs, the duration is 4 years for general/ordinary level and 5 years for specialization level (or preparation of expert teachers) for example in France and Japan. In addition, secondary schoolteachers in some developed countries are obligated to obtain a vocational Diploma as is the case in France, or a Master's degree as is the case in Japan (Gunaima, 1996).

\section{Teacher education and preparation programs provided based on targeted school level}

In many countries, candidates admitted to educational colleges and institutions are enrolled in and prepared for different levels of schooling within a certain teacher program. The aim behind this variety of schooling preparation is for the purpose of providing well-qualified teachers to teach in each level. The academic provision is therefore diverse and directed to satisfying the needs of each targeted level and its students. In another way, in each teacher program there are, for example, 'Pre-school', and 'Basic education' teacher preparation programs. In France, Germany and Japan, the latter usually divides into two mini-programs, namely, 'junior secondary schooling' and 'technical schooling'. By contrast, there is only a one-size-fit-all academic program that is designed for all levels of schools in some states in the US and Germany (Hafiz, 2003). 


\section{Educational professionalization}

As observed, teacher education and preparation academic programs differ considerably in the way in which academic, educational, cultural and technical taught courses are distributed throughout all the academic years of study. To illustrate:

a. Some academic programs oblige candidates to first join and study educational taught courses package for two years, followed by other academic taught courses package for a further two years.

b. Conversely, in other universities, the academic taught courses package are taught during the first two years, and two more years are assigned for studying the educational courses package.

c. Other universities do not prefer a specific package of courses for a candidate to start with. Instead, they allow the candidate the freedom to select the package or the course that he/she prefers to take or study at any point in the program. Thus, candidates can study a combination of both academic and educational courses during the four years of preparation.

Again, it is necessary to realize that every system of teacher education and preparation outlined above has its advantages and disadvantages. Likewise, every university has its own justifications and views regarding what a particular system of education and preparation should implement (Al-Sharqawi, 2004).

\section{Literature Review}

Despite many research studies having investigated teacher education and preparation in the Arab word or internationally, we cannot consider all this literature. We specify and refer to some very relevant (Teddlie \& Reynolds, 2000), and more recent and varied overviews. More appropriately, in the present study, we restrict ourselves to a systematic comparison between these identified selective pieces of literature, which were critically reviewed. Furthermore, our own reflections about what we reviewed were also developed, and have been taken into account in presenting the literature and recommendations of this study.

Abdulla (2011) sought to examine and evaluate the education and preparation academic program of Mathematics teacher at a college of education at the Sudan University of Science and Technology. The researcher relied on descriptive methods and selected a sample of participants from college staff members for conducting his study. A questionnaire of 68 total quality standards was designed for this purpose. Data analysis was undertaken using different statistical techniques such as arithmetic means, percentages, Chi square, split-half and correlation coefficient. The results indicate that, while the objectives and outputs of professional development programs for Mathematics teachers in that particular context significantly complied with objectives and outputs of the evaluation standards in Sudan University for Science and Technology (SUST), the plan and processes of the program complied at a moderate level with SUST's plan and processes, respectively. However, the academic program's inputs also complied with the inputs evaluation standards, albeit at a very low level. In the light of these results, there is a need to establish a specific unit takes over the responsibility of college of education academic program evaluation. Moreover, it was recommended that great attention be paid to building more facilities in the college such as resource rooms/centers, laboratories, maintenance and halls, and to increasing the extra-curricular activities.

AL-Mutwali (2004) conducted a research study using descriptive methods to identify the limitations and obstacles encountering education colleges in Egypt, while also stressing the need for academic work refinement to cope with new changes and challenges taking place in the world at large. Moreover, he sought to identify approaches, agencies and procedures to theorizing about academic accreditation as a concept using examples from developed countries i.e. England, Scotland and the US. The research study suggests a list of academic accreditations for education colleges/institutions that could be used as a reference point to measure the quality of work being done while the academic program is underway. The study has concluded with a future vision of how education colleges/institutions must look like, and how to achieve quality and good performance.

Ayel \& Uwaiyed (2003), on the other hand, attempted to explore the perception of public school teachers and principals about the recent trends relating to teacher education and preparation taking into account the ongoing international changes. The study has revealed that the global changes and challenges demand an increasing commitment from education system to considering recent trends in academic programs of teacher education and preparation. In particular, the study shows a consensus among the sample that the trends witnessed in the developed countries has a significant impact on the academic programs of teacher education and preparation, and also indicates that the top-five trends that had the greatest impact' were as follows: computer (and applications) use; educational technology and communications; teaching methods and approaches improvement and diversification; collaborations between various academic programs/institutions; and assessment practices.

Baghdadi (2000) also aimed in his research to explore and outline teacher selection polices in addition to the standards 
of selection. One of the significant recommendations that this study comes up with is that education and preparation of schoolteachers should be considered similarly to the preparation of the physician doctor in its importance and way. In other words, teacher education and preparation programs offered by colleges would be better if they expanded to include one more year of study (after graduation), which ends by offering the candidate a teaching license that allows he/she to enter the job market as a professional. As such, the creation of an apparent linkage between teacher education and preparation academic programs (in colleges) and schools is viewed as a crucial element. Yet the study shows that it is imperative to involve teachers unions and associations in the process of offering teaching licensures. Studies state that the licensure process may not allow full gains of the process itself if it cannot result in improving teachers (Goldhaber $\&$ Hansen, 2010).

This is expected in order to minimize the rigid intervention of top education authorities in this issue, which would allow relief for schools and positively benefit teacher employment. The study also asserts that there is a need to design candidate admission and enrollment appropriate policies, and curriculum development plans in education colleges through the fair representation of people involved in education i.e. in provinces and teachers unions. The researchers believe that this would be better insofar as the job market is concerned.

\section{Reflection on the Literature Review}

After reviewing some of the literature and existing publications and scholarly work related to the topic, the researchers were able to make a clear reflection on the enquiry undertaken. This being said, specific measures of teacher education and preparation in the Arab world e.g. admission and enrollment policies and academic programs offered by colleges, such as those listed below were noticed:

- Teacher programs in colleges should cover a period of 5 years or more. This is essential and represents sufficient cycle time for teacher education and preparation, and should include taught specialized theoretical courses, internships and fieldwork experiences. The logic behind this is to convey taught theories of instructions, curriculum, pedagogical approaches and assessment into practices in the field.

- Education colleges/institutions and/or their affiliations are to be the primary and sole sources for providing teacher education and preparation academic programs in Arab countries.

- Plan, curriculum, instruction and pedagogy should be incorporated in the design of teacher education and preparation programs. Such design should be determined in an efficient way able to meet and deal with the speedy changing global policies and trends in education accompanied by changes in teaching and learning practices. Furthermore, special care should to be paid to assessment process and practices.

- Colleges of education should work on attracting and retaining excellent students who are passionate about teaching and their profession. This involves establishing a promising (pre-, on- and post-service) system of recruitment standards and qualifications requirements, pay, incentives and compensation, and professional development that is accompanied by encouraging retirement policies for teachers and principals. Doing this allows us to find the best possible teachers in classrooms who can contribute to change for the better.

- The provision and continuous improvement of high-quality teacher education and preparation academic programs and in-service training and professional development to increase the quality of classroom practices and assessment.

- Investing in preparing schoolteachers university programs and in-service on-going professional development in the Arab World based on accredited standards. This investment should be guided by investment in research. According to Davies (2007, p. 181), "transforming education isn't about the "latest great idea." [...] It is about building on the research and finding ways to make the seemingly impossible both possible and practical". Therefore, increasing investment in research in education in the region is a necessity.

- Implement policies related to 'accreditation', 'quality assurance', 'science' and 'technology transfer' as means for more professionally involvement in global education and neoliberalism. Yet countries in the Arab world could draw benefit from other (developed) countries' experiments in this regard. Portnoi (2005, p. 355) asserts that "with careful research and planning, however, countries are able to allow sufficient time to review other countries' policies, borrowing what is relevant and adapting what is not to fit the local context".

- A full teaching licensure system for the registration and licensing of schoolteachers mapped with accredited standards should be implemented to support measuring the practices of teachers in classrooms. It indicates the degree of knowledge and skills - in comparing to the specific adopted accredited standards - to be accomplished by candidates. This would bring out the best of them and build their capacity as professionals. This system must be a pre-requisite for employment in schools in the region. 


\section{Results and Implications}

The findings and implications of the study have been drawn through a systematic comparison between surveyed literature and the researchers' own reflections. The focus of this study is to provide an overview and insights into the nature of teacher education and teacher preparation and professional development programs in the Arab world in the light of recent global trends. This study provides meaningful implications to policy-makers, universities, educational colleges and institutions, and academics and educators involved in teacher education and professional development research. Overall, the empirical findings of this study demonstrate that we are unlikely to find teachers who can efficiently do their job in the classroom without being academically well-prepared. Trained teachers able to use different pedagogical approaches, teaching styles and assessment techniques in classrooms are a priority for schools.

The results also indicate that in-service trainings for teachers increases and professionally develops their knowledge, and potential competencies and skills. This has been found to be a key objective of educational colleges/institutions in the Arab world for comprehensively preparing good teachers in relation to the requirements of recent global trends. Our investigations have shown that some successful experiences and lessons should be carefully learned from teacher programs designed in developed countries. Arab countries must benefit from different experiments and practice in these developed countries in order to raise the standards of their academic programs, while taking great caution and careful implementing relevant borrowed and best-fitted policies to the local context. In this respect, we strongly recommend that a priority - in the region - must be afforded to investment in teacher education and trainings. In our view, that would help in minimize the side effects of the policy borrowing. This also involves investing in establishing a promising (pre-, on- and post-service) system of recruitment standards and qualifications requirements, pay, incentives and compensation, and professional development that is accompanied by encouraging retirement policies for teachers and principals. Such efforts positively affect the social and financial status of teachers. This investment must be guided by investment in research.

This study enhances the existing body of knowledge by specifically suggesting that a "five-year" preparation program for teachers is ideal for the Arab world. We argue that such program should be integrated into the higher education system due to its feasibility, affordability as well as lower financial costs. We further suggest that the components of existing teacher programs - i.e. vision, plans, curriculum etc. - in education colleges must be subject to evaluation and constant reviewing for further development. In so doing, a balance between educational and academic course packages courses/subjects needs should be also achieved.

Many practices can be utilized effectively in teacher preparation programs. Adaptation of rigorous selection criteria that provides the opportunity to select good, brilliant and talented candidates is a traditional and popular practice in teacher programs.

Professional development needs to be more challenging and to have a positive and favorable impact on teachers in schools. The final goal of teachers as professionals is to build capacity through diverse opportunities for life-long learning, but this is a worthy pursuit through raising their professional standards and offering them coherent school-based in-service teacher training and a system of teaching licensure.

However, the most important recommendation made by this study is the establishment of fully-equipped teacher training centers in every college of education in the Arab world, under the supervision of top authority, and the creation of experimental environments for candidates to practice what they have learned in their colleges and effectively and practically apply it in the field. Furthermore, educators and researchers should work on issues relating to teacher education by contributing through symposia, debates and conference, and commissioning research to prepare teachers for the challenges that they may experience in the classroom.

\section{References}

Abdulla, A. (2011). Evaluation of Mathematics Teacher Professional Development in the Department of Science, College of education, Sudan University for Science and Technology in View of Total Quality standards and Excellence, University for Science and Technology: Sudan.

Abdulsalam, M. (2006). Basics Teaching and Teacher Professional Development. The New University House: Alexandria

Ahmed, D. (2007). Teacher profession Accreditation in view of some developed countries experiences. The new university House: Alexandria.

Al-Badani, G., \& Lulua, M. (2005). Evaluation of Teaching Practice at College of Education University of Sanaa. Yemen, Unpublished Master dissertation, College of Education University of Sanaa, Yamen.

Al-Beelawi, H. (2004). Development of Colleges of education in the light of international Quality Standards- 
Educational Accreditation, Department of Foundations of Education Conference "Educational and Sustainable Development". College of Education - University of Zagazeeg, Egypt.

Al-Deeb, B. (1992). Comprehensive Planning Mechanisms for Educational Reform, Educational Document from U.S.A. Gull Countries Educational Bureau, Riyadh.

Al-Mustafa, S. (2010). Evaluation Basic Un published M.A dissertation, University of Khartoum, Sudan.

AL-Mutwalli, I. (2004). Future Vision of Colleges of Education in View of a Referenced Framework in Academic Accreditation, Unpublished Ph.D. Thesis, College of Education University of AL- Manoufia, Egypt.

Al-Shargawi, M. (2004). Future vision for the Development of College of Education in the light of Educational Accreditation Standards, in light of Educational Accreditation Standards. Journal of College of Education, University of Zagazig, Egypt.

Al-Utaibi, M., \& Ghanib, M. (1996). Suggested Standards for Academic and Professional Accreditation of Teacher Preparation Programme in Arab Universities. Arab Gulf Call, Year 16, $58^{\text {th }}$ Ed.

Ayel, H., \& AL-uwaidy, A. (2003). Modern Trends in Teachers Preparation for General Education in view of the Global Changes, Psychological and Educational Research Journal, College of Education University of AL-Manoufia, Egypt.

Baghdadi, M. (2000). Pre-University Teacher Selection and Employment Polices, A comparative study between Egypt and Americaj Unpublished M.A dissertation, institute of Educational studies, University of Cairo, Egypt.

Bray, M. (2005). Comparative Education Policy and Globalisation: Evolution, Missions and Roles, in J. Zajda (ed.), International handbook on globalisation, education and policy research: Global pedagogies and policies, 35-48. Dordrecht: Springer. https://doi.org/10.1007/1-4020-2960-8_3

Darling-Hammond, L. (2000). Teacher quality and student achievement: A review of state policy evidence, Educational Policy Analysis Archives, 8(1), 1-42. https://doi.org/10.14507/epaa.v8n1.2000

Darling-Hammond, L., Holtzman, D. J., Gatlin, S. J., \& Heilig, J. V. (2005). Does teacher preparation matter? Evidence about teacher certification, Teach for America, and teacher effectiveness. Education Policy Analysis Archives/Archivos Analíticos de Políticas Educativas, 13, 1-48. https://doi.org/10.14507/epaa.v13n42.2005

Davies, A. (2007). Leading towards learning and achievement: The role of quality classroom assessment. In J.M. Burger, C.F. Webber, \& P. Klinck, (Eds.), Intelligent leadership constructs for thinking education leaders, 6, 159-182. London: Springer. https://doi.org/10.1007/978-1-4020-6022-9_9

Down, B. (2012). Reconceptualising teacher standards: Authentic, critical and creative. In B. Down \& J. Smyth (Eds.), Critical Voices in Teacher Education- Teaching for Social Justice in Conservative Times (Vol. 22), 63-80. Dordrecht, Heidelberg, New York, London: Springer publications. https://doi.org/10.1007/978-94-007-3974-1_5

Ellili-Cherif, M., Romanowski, M. H., \& Nasser, R. (2012). All that glitters is not gold: Challenges of teacher and school leader licensure licensing system in Qatar. International Journal of Educational Development, 32(3), 471-481. https://doi.org/10.1016/j.ijedudev.2011.11.010

Evagorou, V., Dillon, J., Viiri, J., \& Albe, V. (2015). Pre-service Science Teacher Preparation in Europe: Comparing Pre-service Teacher Preparation Programs in England, France, Finland and Cyprus, Journal of Science Teacher Education, 1(26), 99-115. https://doi.org/10.1007/s10972-015-9421-8

Ferguson, R. F. (1991). Paying for public education: new evidence on how and why money matters, Harvard Journal on Legislation, 28(2), 465-498.

Gibrael, B. (1983). The technological and scientific revolution requirements for Teacher professional preparation, Arabic Journal of Education, Tunisia, $3,1^{\text {ts }}$ Ed.

Goe, L. (2002). The distribution of emergency permit teachers in California. Educational Policy Analysis Archives, 10(42), 1-36. https://doi.org/10.14507/epaa.v10n42.2002

Goldhaber \& Hansen. (2010). Licensure testing? Race, gender, and teacher testing: how informative a tool is teacher licensure testing, American Educational Research, 47, 218-251. https://doi.org/10.3102/0002831209348970

Gunaima, M. (1996). Policies and Programmes of Arab Teacher Preparation and the Teaching - Learning Process Structure, $1^{\text {st }}$ Ed. Egyptian - Lebanese House: Cairo.

Hafiz, H. (2003). A comparative study of Educational Accreditation Systems for Teacher Preparation Programmers in Same Foreign Countries and what Extent they are made use of in Egypt. A paper Submitted to the Eleventh Anal Conference: Total Quality in Teacher Preparation in the Arab World for A New Millennium, University of Helwan, 
College of Education, 12-13 March

Humood, R. (2003). International Trends in Teacher Preparation in Arab Countries. Lebanon Agency for Educational Sciences: Beirut.

Hunt, S. D. (1992). "Marketing is ...", Journal of the Academy of Marketing Science, 20, 301-311. https://doi.org/10.1007/BF02725205

Ketch, M. (2001). Philosophy of Teacher Preparation in the light of Contemporary Challenges. ${ }^{\text {st }}$ Ed., Book Publishing Centre.

Madani, G. (2002). Developing higher education as a ttuinan Development Component in Saudi Arabia, A Scientific Paper Presented to the "Saudi Economy until 2020" Symposium, Riyadh, Saudi Arabia.

Madhavaram, S., \& Laverie, D. A. (2010). Developing pedagogical competence: Issues and implications for marketing education. Journal of Marketing Education, 32(2), 197- 213. https://doi.org/10.1177/0273475309360162

Portnoi, L. (2005). Employment Equity and Higher Education: Policy Borrowing and the Politics of Language. In J. Zajda (ed.), International Handbook on Globalisation, Education and Policy Research, 351-365. Dordrecht: Springer. https://doi.org/10.1007/1-4020-2960-8_22

Teddlie, C., \& Reynolds, D. (2000). The international handbook of school effectiveness research. London, UK: Falmer.

Wajeeh, F., \& Michael, D. (2006). Basics of Teacher Professional Development, $1^{\text {st }}$ Ed: . Amman, Jordan: Al-Warrag establishment.

Wenglinsky, H. (2000). How teaching matters: Bringing the classroom back into discussions of teacher quality. Princeton, NJ: Educational Testing Service.

Yahia, H. (2003). Teacher Preparation between Globalization and Development Plans in the Gulf States, a paper Submitted to the Conference, University of Kuwait, College of Education, October 12-14.

Zavadsky, H. (2009). Bringing School Reform to Scale: Five Award-Winning Urban Districts. Educational Innovations. Cambridge: Harvard Education Press.

\section{Copyrights}

Copyright for this article is retained by the author(s), with first publication rights granted to the journal.

This is an open-access article distributed under the terms and conditions of the Creative Commons Attribution license which permits unrestricted use, distribution, and reproduction in any medium, provided the original work is properly cited. 